\title{
Sociološki osvrt na odrednice studentskoga internetskog kupovanja u Hrvatskoj
}

DOI: $10.5613 /$ rzs.50.1.2 UDK: 366-057.875:004.7](497.5)

658.8:004.7](497.5)

316.728-057.875:336.1 ](497.5)

Izvorni znanstveni rad

Primljeno: 17. 7. 2019.

\author{
Ivana BRSTILO LOVRIĆ \\ Hrvatsko katoličko sveučilište, Hrvatska \\ ivana.brstilo@unicath.hr
}

\section{SAŽETAK}

Valorizirajući internetsko kupovanje kao aktualan fenomen koji je zadnjih godina $u$ globalnom porastu, ovim radom se ukazuje na deficit društvenih, napose socioloških, analiza na temu u kontekstu hrvatskog društva. Pregledom literature o profilima internetskih kupaca postavljen je okvir za ispitivanje studentske populacije koja je prepoznata kao predvodnik suvremenih potrošačkih i tehnoloških trendova. Operacionalizacijom viševrsnih forma kapitala uz varijable demografije, tehnoloških resursa i praksi, ispitane su odrednice studentskoga internetskog kupovanja u Hrvatskoj $(\mathrm{N}=1094)$. Izvorni empirijski nalazi prikupljeni metodom ankete pokazuju da studentsko internetsko kupovanje najpouzdanije predviđaju posjedovani tehnološki resursi, tehnološke vještine i interesi na način da su ispitanici opremljeniji novim tehnologijama s izraženijim tehnološkim vještinama i interesom za praćenjem tehnoloških trendova vjerojatniji internetski kupci. Aspekti tehnoloških resursa i praksi udruženi s ekonomskim kapitalom utvrđeni su značajnima i kod razlikovanja studenata koji (ne)kupuju putem interneta, što je podcrtalo višerazinske nejednakosti u perspektivi studentskog internetskog kupovanja. Izražena zabrinutost oko online rizika te tradicionalna (ne) vezanost za fizičku kupovinu ispostavili su se glavnim razlozima neprakticiranja internetskog kupovanja iz perspektive ispitanika, što je razvojnu dinamiku same prakse zaokružilo temama društvene nejednakosti i nepovjerenja.

Ključne riječi: internetsko kupovanje, internetski kupci, studenti, Hrvatska, kapital, tehnološki resursi i prakse, online rizici

\section{UVOD}

Internet je na globalnoj razini promijenio način na koji suvremeni ljudi komuniciraju, informiraju se, zabavljaju, ali i kupuju. Masovni razvoj novih tehnologija utoliko je iznjedrio niz karakterističnih fenomena među kojima se nalazi i internetsko kupo- 
vanje - koje se u ovom radu razumijeva kao individualna praksa kupovanja proizvoda i usluga putem interneta bez posrednika (Farag i dr., 2006; Choudhury i Dey, 2014). Njegovom popularizacijom zadnjih godina perspektiva o potrošačkim praksama više ne podrazumijeva samo fizičko, nego i virtualno, online okruženje. Ono je postalo svojevrsnim standardom u brojnim europskim zemljama poput Danske, Velike Britanije i Nizozemske u kojima otprilike 8 od 10 stanovnika kupuje putem interneta. Od 2014. godine polovina ukupne populacije zemalja članica Europske unije prakticirala je internetsko kupovanje, s time da ih je 2018 . godine bilo $60 \%$ (Eurostat, 2014-2018). U Sjedinjenim Američkim Državama 2018. godine online prodajom ostvareno je 504,5 milijardi američkih dolara uz predviđanja daljnjeg širenja online tržišta (The StatisticsPortal, 2019).

lako znatno skromniji, u Hrvatskoj su također očiti trendovi rasta internetskog kupovanja, pa se tako od $23 \%$ internetskih kupaca u 2012. godini njihov udio u 2018. godini popeo na 35\% (Eurostat, 2012-2018). U općoj populaciji Hrvatske, a onda i Europske unije, mladi i studenti su zadnjih godina među vodećim internetskim kupcima te ih više od polovine kupuje putem interneta (Eurostat, 2013-2018). Za to su stvorene dobre pretpostavke s obzirom na to da većina mladih i studenata u Hrvatskoj ima pristup internetu te ga u odnosu na druge skupine češće koriste (DZS, 2018). No, u usporedbi s europskim vršnjacima, susreću se s nižom kvalitetom infrastrukture s obzirom na to da je Hrvatska po brzini interneta među najsporijim zemljama u svijetu (Spajić Vrkaš i Potočnik, 2017). Spomenimo i to kako je uvjerljiva većina hrvatskih kućanstava u 2018. godini imala pristup internetu (82\%), no pritom nismo dosegnuli prosjeke Europske unije (89\%) što osobito dolazi do izražaja u odnosu na Veliku Britaniju (95\%) i Nizozemsku (98\%), kao i zemlje u okruženju poput susjedne Slovenije (87\%) ili Austrije (89\%) (Eurostat, 2018). Slično kao i kod drugih mladih u svijetu, i u Hrvatskoj je njihovo korištenje računala orijentirano na pretraživanje, slušanje glazbe, komuniciranje, korištenje društvenih mreža, dok je u zadnjem desetljeću zabilježen porast pretraživanja interneta te korištenja računala za učenje i vježbanje uz pad učestalosti crtanja, programiranja i igranja računalnih igara (Spajić Vrkaš i Potočnik, 2017: 132). U rasponu od jedanaest godina (od 1999. do 2010. godine) među medijskim navikama studentske populacije u Hrvatskoj je zabilježen porast upravo kupovanja putem interneta što je "domena koja polagano ali stabilno raste, uz značajan pad studenata koji nikada nisu kupovali preko interneta" (Potočnik, 2014).

Profiliranje interneta kao komercijalnog medija tekući je predmet globalnoga znanstvenog interesa. Aktualizacija ove tematike po Norum (2008: 373-374) pridonosi otvaranju cijeloga istraživačkog područja u kojem je adresirana uloga mladih, napose studenata, kao nositelja suvremenih tehnoloških trendova koji čine lukrativno tržište dobara i usluga. Stoga ne čudi da su upravo oni učestalo ispitivana 
populacija na temu internetskog kupovanja u međunarodnoj literaturi (Lammers i dr., 2003; Dittmar, Long i Meek, 2004; Lester, Forman i Loyd, 2005; Park i Kim, 2007; Norum, 2008; Ciunova-Shuleska, Grishin i Palamidovska, 2011; Kiyici, 2012; Choudhury i Dey, 2014; Aziz i Wahid, 2018). Dijelom je to slučaj i u Hrvatskoj u kojoj se nekolicina znanstvenih radova, uglavnom iz područja ekonomije, bavi istraživanjem studentskih stavova i iskustava u internetskom kupovanju te problemima i prednostima u odnosu na klasične trgovine (Strugar, Knežević i Jaković, 2011); faktorima koji utječu na studentsku kupovinu s internetskih stranica za grupnu kupovinu (Bralić, Jadrić i Ćukušić, 2014); stavovima studenata o etičnosti prodaje online maloprodavača (Anić, Marković i Vouk, 2013); potrošačkim praksama mladih generacija u kontekstu kompulzivnosti, impulzivnosti i funkcionalnosti (Vojvodić i Matić, 2015); motivima kupovanja odjeće i kriterija odabira trgovina (Knežević, Delić i Ptić, 2016); korištenjem društvenih medija (Štulec, Petljak i Naletina, 2018).

Neki sociolozi primjećuju kako su ekonomski i marketinški pristupi potrošnji i potrošačima individualističkog svjetonazora te polaze od "pojedinca bez osobnosti, s određenim potrebama koje potrošnjom zadovoljava" (Peračković, 2013: 30). Sociološka perspektiva pak valorizira sociokulturnu pozadinu potrošnje i potrošačkih praksi, adresirajući njihovu historijsku transformativnost. Ista bi se mogla označiti prijelazom iz sfere racionalnih potreba u sferu želja uz prateću zamjenu realnoga za imaginarno, što će Campbell (1987) još krajem osamdesetih godina 20. stoljeća prepoznati kao romantičarski naboj razvijajućega kapitalizma. Njegova kasna faza stoga biva obilježena paradigmom potrošačkog hedonizma kojem je samo potrošačka imaginacija granica, a što se na osobit način reflektira na kulturu mladih, posebice u dijelu onoga što Gronow naziva ekonomijom želja i snova, u odnosu na ekonomiju potreba (prema Pedrozo, 2013: 25-26). S uzletom ekonomije želja i snova na važnosti dobiva uloga pojedinca usmjerenog na žongliranje između heterogenih opcija potrošačkog izbora kao svojevrsnih životnostilskih markera. Giddens (1991) spominje kako je socijalna otvorenost posttradicionalnog stadija modernosti prijemljiva za osobna rješenja u (re)kreiranju vlastite svakodnevice $i$ biografskih narativa, ali imajući na umu različite klasne i socijalne formacije koje onda koče ili onemogućavaju mehanizam osobnog izbora. Utoliko su suvremeni poticaji samoaktualizacije u koliziji s različitim strukturalnim rizicima i biografskim opterećenjima. Istaknuto posebno dolazi do izražaja u tranzicijskim i postsocijalističkim društvima pa neki sociolozi u kontekstu hrvatskog društva problematiziraju pristup individualizacije smatrajući kako su životne pozicije mladih uvelike određene socioekonomskim i sociostrukturnim zadatostima na kojima je onda nužno temeljiti analizu njihove kulturne dimenzije života kao što su slobodno vrijeme $i$ potrošnja: "današnja generacija mladih koja sazrijeva u uvjetima društvene krize, može manje nego prijašnje generacije, koristiti različite kanale socijalne promo- 
cije, prije svega zato što društvena potpora nije adekvatna zbog čega sve veći značaj dobivaju obiteljski resursi, odnosno socioklasno oblikovane mogućnosti i ograničenja" (Ilišin, 2014: 15). Shodno tome, odnos mladih prema potrošnji i novim tehnologijama može se sagledati iz različitih kanala nejednakosti od kojih su neki sustavniji poput socioekonomskih čimbenika, dok su neki novijeg datuma poput posjedovanja odnosno, vještina korištenja novih tehnologija (van Deursen i van Dijk, 2014). Upravo (novo)nastale nejednakosti na tehnološkoj osnovi dodatno produbljuju postojeće društvene podjele, što na poseban način determinira status uključenosti ili isključenosti mladih iz razvojnih tokova potrošačkog društva, upozorava Pedrozo (2013). Tako se s referencama autonomije i osobnog izbora u potrošačkim i tehnološkim praksama otvara pitanje osobnih (ne)mogućnosti koje će neki sociološki pristupi u bourdieuovskoj perspektivi artikulirati pojmovima kapitala kao stečenih ili naslijeđenih resursa, svojevrsnih strateških dispozicija za uspjeh na različitim društvenim poljima. "Struktura distribucije različitih vrsta i podvrsta kapitala u danom trenutku predstavlja imanentnu strukturu društvenog svijeta, tj. skup ograničenja, upisanih u samu stvarnost toga svijeta koja na trajan način upravlja njegovim funkcioniranjem, određujući šanse za uspjeh u praksi" (Bourdieu, 1997: 46). Dok se sam autor usmjerio na istraživanje odnosa kapitala i obrazovanja na primjeru francuskog društva iz druge polovine 20. stoljeća, fokus ovog rada je na analizi viševrsnih kapitala i studentskoga internetskog kupovanja u suvremenoj Hrvatskoj ( $\mathrm{N}=1094)$. Tako se smjeralo utvrditi jesu li posjedovani ekonomski, kulturni, socijalni i tehnološki resursi čimbenici studentskoga internetskog kupovanja i sukladno tomu, mogu li se iz konvencionalnoga sociološkog kategorijalnog aparata promišljati suvremeni fenomeni i prakse kao što je internetsko kupovanje. Utoliko se koncepcija socijalnog prostora i nejednakosti premjestila iz fizičkog u virtualni kontekst, što je dalo na suvremenosti istraživačkog pristupa, posebno imajući na umu da u domaćoj sociološkoj literaturi nema podrobnijih istraživanja na temu. Doprinos ovog rada stoga se ogleda u adresiranju suvremenoga društvenog fenomena kakvo je internetsko kupovanje u poveznici s klasičnim pojmovnikom sociološke struke.

Nakon uvodnog dijela, priređen je pregled literature o internetskom kupovanju, pri čemu su izdvojena istraživanja povezana s obrađivanom temom. Potom je predstavljeno autorsko istraživanje odnosno, obavljene kvantitativne analize. Zaseban je osvrt priređen u dijelu kvalitativne analize koja je obuhvatila studente koji ne kupuju putem interneta kako bi se iz njihove perspektive izvidjele razvojne smjernice same prakse i potencijalnih istraživanja, a što se u zaključku zaokružuje pregledom najvažnijih nalaza. Slijedi, dakle, pregled referentne literature. 


\section{PREGLED LITERATURE}

Temeljne karakteristike internetskog kupovanja ujedno predstavljaju njegove razlike u odnosu na fizičku potrošnju, poglavito mogućnost vremenski neograničene potrošnje bez posjećivanja fizičkog prostora i bez fizičkog kontakta s robom. Internetsko kupovanje popularizirano je kao neprekidna (24/7) aktivnost koja potrošačima štedi vrijeme te im jednim klikom miša omogućava pristup robi cijeloga svijeta. Internetske su trgovine posljedično bitno drukčije od onih tradicionalnih u kojima potrošač u materijalnom okruženju i fizičkoj interakciji s robom i prodavačem opcionalno plaća gotovinom ili karticom. Stoga, iako je internetsko kupovanje novi(ji) fenomen, nerijetko se sagledava u odnosu na tradicionalnu ili fizičku kupovinu pa je korpus literature posvećen temama koje su u fokusu ovoga rada - rodnim, dobnim, ekonomskim, kulturnim, tehnološkim i socijalnim profilima internetskih kupaca.

Rodni profil internetskih kupaca sastavni je dio brojnih studija od kojih neke izdvajaju muškarce tipičnijim odnosno, brojnijim internetskim kupcima od žena (Lammers i dr., 2003; Farag, Dijst i Lanzendorf, 2003; Farag i dr., 2007; Strugar i dr., 2011; Choudhury i Dey, 2014). Iz istraživanja Kiyici (2012) doznalo se da studentice više od studenata percipiraju financijske i vremenske rizike virtualnog načina kupovanja što je u skladu s nalazom Strugara i suradnika (2011) o većoj kritičnosti hrvatskih studentica u odnosu na studente o internetskom kupovanju u usporedbi s klasičnim trgovinama. Dodatne potkrepe temi pružilo je istraživanje Ciunova-Shuleske i suradnika (2011) prema kojemu su studenti iskustveniji internetski kupci od studentica te više uočavaju prednosti tog načina kupovanja smatrajući da pruža bolju ponudu proizvoda i cijena od tradicionalnih trgovina. Ovi i slični nalazi, prema Dittmar i suradnicima (2004), mogu se objasniti manjom otvorenosti žena prema novim tehnologijama te njihovim nižim tehnološkim vještinama u odnosu na muškarce, što se onda odražava u dijapazonu rodnih razlika pri korištenju interneta i samoj praksi internetskog kupovanja.

Međutim, primjetna je ambivalentnost istraživačkih spoznaja na ovu temu. Dok se $s$ jedne strane naglašava veća brojnost i otvorenost muškaraca prema internetskom kupovanju, pojedini autori ističu da muškarci više kupuju online, ali žene više troše kupujući na taj način (Brown, prema Choudhury i Dey, 2014). Istraživanje Park i Kim (2007) tako tvrdi da su studentice jedna od najaktivnijih grupacija internetskih kupaca s najvećim tržišnim potencijalom razvoja elektroničke maloprodaje. Uputni su nalazi o razlikama žena i muškaraca u stavovima i aspiracijama spram opcija internetskog kupovanja (Dittmar i dr., 2004) te različitim preferencijama studentica i studenata spram preferencijskih kategorija online proizvoda (Strugar i dr., 2011; Kiyici, 2012). Neki izvori pak demantiraju značajnost spola u prakticiranju internetskog kupovanja (Soopramanien i Robertson, 2007; Akhter, 2012). Na tom 
tragu Hernandez, Jimenez i Martín (2011) izvještavaju o smanjenju rodnih razlika u kontekstu korištenja novih tehnologija uz komentar kako su iste značajne samo u inicijalnoj fazi tehnološkog priučavanja odnosno, stjecanja iskustva. Bigne, Ruiz i Sanz (2005) mišljenja su kako je s razvojem novih tehnologija došlo do promjene društvenih navika, pri čemu su žene sve iskusnije i aktivnije korisnice interneta, što se onda odražava i na internetsko kupovanje.

Uz rod, ovo istraživanje uključuje dobni aspekt internetskih kupaca za koji je Akhter (2012) ustvrdio da nije uniforman u znanstvenoj literaturi, iako se načelno ističe veća sklonost kupovanju putem interneta kod mladih nego starijih generacija (Swinyard i Smith, 2003; Akhter, 2003; Bigne i dr., 2005; Hernandez i dr., 2011). Lester i suradnici (2005) razlažu primjere studija s početka trećeg milenija kad mladi nisu bili vodeći internetski kupci u odnosu na starije generacije. Dapače, postojala je određena prednost potonjih, da bi u kratkom vremenu prevladao praktični interes mladih za tom potrošačkom praksom. Istraživanjem su utvrdili i da mladi prednjače u kupovanju određenih internetskih usluga (poput kupnje koncertnih karata) te opipljivih proizvoda (poput odjeće) što je ukazalo na mladenačke potrošačke online preferencije. Također su uočene diskrepancije unutar pojedinih potkategorija mladih. Suprotno pretpostavci o većoj otvorenosti mladih za suvremene potrošačke i tehnološke trendove, istraživanje Norum otkrilo je da su stariji studenti više kupovali putem interneta od mlađih kolega (2008).

Nakon roda i dobi, fokus je na povezivanju internetskog kupovanja s različitim vrstama kapitala kojima je u ovom radu dana posebna pozornost kako bi se pridonijelo sociološkoj aktualizaciji teme o kojoj nema podrobnijih uvida u struci. U pogledu toga kapitali kao uvriježeni sociološki koncepti mogu ponuditi stručni ulaz u tematiku koja se u društvenim znanostima uglavnom obrađivala iz ekonomske perspektive. S time valja primijetiti da u literaturi o internetskom kupovanju koncepti kapitala nisu višedimenzionalno obrađivani, nego se pozornost pridavala samo njihovim pojedinim aspektima. Uglavnom je bila riječ o istraživanju obrazovanja i prihoda koji predstavljaju samo jedan vid kulturnog odnosno, ekonomskog kapitala kao dinamičnih složenica s viševrsnim dimenzijama. Imajući to na umu, neki izvori informiraju da veći stupanj obrazovanja i prihoda stimulira internetsko kupovanje (Farag i dr., 2006; Soopramanien i Robertson, 2007; MasterCard Worldwide Insights, 2008; Perea y Monsuwé, Dellaert i de Ruyter, 2004; Kiyici, 2012; Choudhury i Dey, 2014). Prema Norum (2008), obiteljska ekonomska situacija oblikuje potrošačke prakse svojih članova na način da će studenti iz obitelji s većim prihodima vjerojatnije češće kupovati putem interneta od studenata s nižim obiteljskim prihodima. Slično tomu, Swinyard i Smith (2003) ustanovljuju da su osobni prihodi, prihodi kućanstva te stupanj obrazovanja značajno veći kod internetskih kupaca u odnosu na one koji ne kupuju putem interneta odnosno, u slučaju istraživanja 
Soopramaniena i Robertsona (2007), niži prihodi su obilježja osoba koje ne kupuju putem interneta ili ga koriste samo za pretraživanje. No, te nalaze ne treba uopćavati jer postoje i oni koji pobijaju učinak obrazovanja na prakticiranje internetskog kupovanja (Akhter, 2012; Choudhury i Dey, 2014). Isto je i s prihodima koji, po Hernandez i suradnicima (2011), nisu značajni u kontekstu interneta kao otvorenog i prilagodljivog medija za korisnike svih socijalnih i profesionalnih statusa. lako to nije bio slučaj u njegovoj početnoj fazi, zbog omasovljivanja i pojeftinjenja računala te priključaka za internet, taj se medij profilirao u praktičnu socijalnu alternativu znatno skupljim fizičkim trgovinama te je kod iskusnih tehnoloških korisnika razina prihoda izgubila na efektu (Hernandez i dr., 2011).

Tako dolazimo do sekcije pitanja vezanih uz nove tehnologije koje su u ovom radu obuhvaćene dvjema razinama. Prva je razina nazvana tehnološka opremljenost te se odnosi na posjedovanje različitih vrsta tehnologija. Druga razina odnosi se na takozvane tehnološke prakse te obuhvaća aspekte praćenja tehnoloških trendova, samoprocjenu tehnoloških vještina i dnevno korištenje interneta. Da je pitanje odnosa s novim tehnologijama prožeto različitim formama nejednakosti misle Van Dijk i Hacker (2003) spominjući materijalni pristup koji obuhvaća dimenziju posjedovanja tehnologija poput računala i internetskog priključka. Upravo je ta dimenzija u ovom radu analitički odvojena kako bi se pomnije istražila njezina zasebna uloga u oblikovanju studentskoga internetskog kupovanja te umreženost sa srodnim čimbenicima kakvi su posjedovani ekonomski resursi. Potkrepu tomu daju i drugi izvori prema kojima se tehnološke nejednakosti međusobno isprepleću s onim ekonomskima pa su tako bolje situirana kućanstava ujedno tehnološki opremljenija, što ih onda predisponira za internetsko kupovanje (Perea y Monsuwé i dr., 2004). Potonje je za mnoge ponajprije forma digitalne podjele no, spomenuti van Dijk i Hacker (2003) komentiraju kako može doći do smjene nejednakosti što i predviđaju u slučaju zamjene materijalnog pristupa onim na razini tehnoloških vještina. Postoje i suprotna mišljenja pa tako Norum (2008) primjećuje kako su se neke studije o internetskom kupovanju fokusirale na opremljenost novim tehnologijama poput računala i internetskog priključka što je sekundarno kod studentske populacije kojima je na raspolaganju cijela tehnološka mreža na kampusima, domovima i sveučilištima pa u pogledu toga nisu tehnološki zakinuti. Drugi su pak radovi stavili naglasak na uvjetovanost internetskog kupovanja s tehnološkim praksama kao što je korištenje računala, interneta i tehnoloških vještina. $U$ više je izvora naglašena važnost tehnoloških vještina u kontekstu kupovanja putem interneta (Hernandez i dr., 2011; Kiyici, 2012; Farag i dr., 2006; Farag i dr., 2007; Dittmar i dr., 2004). U radu autora Swinyard i Smith (2003) se pak navodi kako internetski kupci značajno više koriste računalo, više vremena provode online te im je ugodnije korištenje računala i interneta od grupacije ispitanika koji ne kupuju putem interneta i čiji obrasci 
ponašanja odstupaju od spomenutih. I drugi su autori došli do sličnih nalaza pa tako Ciunova-Shuleska sa suradnicima (2011) zaključuje da su učestaliji korisnici interneta skloniji internetskom kupovanju. Suprotno tomu, Bigne i suradnici (2005) nisu potvrdili učestalost korištenja interneta značajnim čimbenikom odluke o internetskom kupovanju pri čemu jedno od mogućih objašnjenja vide u dominantnom korištenju interneta kao izvora informacija, a manje kao komercijalnog medija. Je li to slučaj i sa studentima u Hrvatskoj i kako se aplicira na njihovo kupovanje putem interneta, ostaje za ispitati.

Posljednja tipologija koja će se uključiti u ovaj rad tiče se socijalnog kapitala. Taj koncept ima široko teorijsko i metodološko određenje, između ostalog se $u$ sociologiji veže uz uopćeno povjerenje (povjerenje prema poznatim ili nepoznatim ljudima) te povjerenje u različite institucije (Pavić-Rogošić, 2007; Nikodem i Črpić, 2014) ako se u toj operacionalizaciji ne eksplicira u kontekstu internetskog kupovanja, što onda naznačuje doprinos ovog rada, opće pitanje povjerenja je jedno od zastupljenijih u referentnoj literaturi. Autori poput Tang i Chi (2005) ističu kako se (ne)povjerenje $u$ internetsko kupovanje generira kroz prepoznatljive karakteristike nesigurnosti, anonimnosti, manjka kontrole i niza rizika vezanih uz dijeljenje osobnih podataka, plaćanja i prilaganja financijskih informacija, nevjerodostojnosti proizvoda, povrata oštećene ili nevaljane robe i nadalje. Stoga su u literaturi sustavno obrađivane teme potrošačkih aktivnosti i iskustava vezanih uz stavke online ponude, kao i s njome povezanih sigurnosnih i financijskih rizika (Lester i dr., 2005; Akhter, 2012; Kumar i Maan, 2014; Aziz i Wahid, 2018; Jordan, Marič i Leskovar, 2018). Iz tih je izvora razvidno da pitanja povjerenja i sigurnosti značajno modeliraju internetsko kupovanje. Prema Grabner-Kraeuter (2002: 44) povjerenje je svojevrsna mentalna strategija za nošenje s neminovnim nesigurnostima koje prati ovaj vid kupovanja poput sistemske nesigurnosti koja proizlazi iz potencijalnih tehnoloških problema i nedostatka pravne regulacije ili transakcijske nesigurnosti koju generira nejednak odnos u distribuciji informacija između uključenih stranaka. Navedeno se može povezati s tezom Raamat i suradnika kako virtualnost internetskog kupovanja odgovara izdizanju i iskorjenjivanju modernih socijalnih praksi iz tradicionalnih normativa, što onda "zahtijeva veliku količinu povjerenja prema ekspertnim sistemima” (2008: 309). Ekspertne sisteme uz simbolične tokene već spominjani Giddens (1991) zaokružuje pojmom apstraktnih sustava čija je sve naglašenija uloga u visokom stadiju modernosti indicirala porast apstraktnosti života koji se izdiže iz lokalnih konteksta odnosno, iskorjenjuje iz prostornih i vremenskih okvira u virtualna i globalna tržišta. Moderni je pojedinac u takvom okolišu primoran vjerovati apstraktnim sistemima usprkos, ili baš zbog, nemogućnosti kontrole i sveobuhvatnog (sa)znanja o istima što ga čini ranjivim subjektom, ovisnim o povjerenju u sisteme kojima se služi. 
S time se zaokružuje teorijski pregled rada koji se dalje usmjerava na empirijski dio u kojem će se predstaviti provedeno istraživanje uz korištene instrumente i njihove analize na kvantitativnoj i kvalitativnoj razini.

\section{OPIS ISTRAŽIVANJA}

\subsection{Istraživački cilj i doprinos}

Opća je svrha ovog rada bila istražiti doprinos različitih vrsta resursa na studentsko (ne)prakticiranje internetskog kupovanja. Njihovim uključivanjem na razini prediktora smjeralo se utvrditi predisponiraju li studentsko participiranje u suvremenim potrošačkim i tehnološkim praksama i shodno tome, jesu li njihove biografije referentnije na terminologiju rizika i nejednakosti ili izbora i autonomnosti. Planiranim analizama stoga se željelo utvrditi mogu li se iz klasičnoga sociološkog kategorijalnog aparata referirati suvremeni fenomeni kao što je internetsko kupovanje i što to znači za kulturu mladih. S obzirom na iznimnu ambivalentnost nalaza u konzultiranoj literaturi o značajnim čimbenicima internetskog kupovanja te malobrojnim istraživačkim studijama o studentskom internetskom kupovanju u Hrvatskoj u sociološkom fokusu, ovaj rad nije orijentiran na testiranje hipoteza, nego na odgovaranje postavljenih istraživačkih pitanja prema naznačenom istraživačkom cilju.

$\mathrm{Na}$ analitičkoj će se razini utvrditi razlikuju li se studenti koji (ne) kupuju putem interneta s obzirom na posjedovane ekonomske, kulturne, tehnološke i socijalne resurse ili su značajnije njihove demografske odrednice i tehnološke prakse poput korištenja interneta, samoprocjenu tehnoloških vještina i praćenje tehnoloških trendova. U svrhu detaljnog ispitivanja teme i davanja smjernica za buduća istraživanja, u završnom dijelu rada će se analizirati osobni razlozi studenata koji ne kupuju putem interneta.

Znanstveni je doprinos ovog rada u rasvjetljavanju čimbenika internetskog kupovanja kao globalno popularne prakse koja nije detaljnije istraživana u hrvatskom kontekstu, posebno ne iz sociološke perspektive koja sagledava šire osobitosti u kontekstu studentskih ekonomskih, kulturnih, socijalnih i tehnoloških profila, kao i problematike društvene (ne)jednakosti s pripadajućim naglascima poput digitalnog jaza i potrošačke isključenosti. $U$ empirijskom i teorijskom smislu rezultati ovog rada korisni su za interdisciplinarna problematiziranja teme koja se mogu usmjeriti na testiranje drugačijeg prediktorskog sklopa uz preporuku korištenja reprezentativnog uzorka. 


\subsection{Mjerni instrumenti}

\section{Ekonomski kapital}

Instrument ekonomskog kapitala čini kompozitna varijabla sastavljena od ukupno devet pitanja koji se odnose na radni status obaju roditelja1 (kućanica/umirovljenik; ne radi, ali traži posao; rad na crno; honorarni rad; zaposlen/a dio radnog vremena kod poslodavca; zaposlen/a puno radno vrijeme kod poslodavca, samozaposlen/a), mjesečne prihode obaju roditelja (manje od 2000 kn; od 2001 do 4000 kn; od 4001 do 6000 kn; od 6001 do 8000 kn; od 8001 do 10000 kn; više od 10000 kn), broj posjedovanih nekretnina u roditeljskom vlasništvu (nijednu; jednu; dvije; tri ili više), broj posjedovanih automobila, motora i bicikla u obiteljskom kućanstvu (na ljestvici od $0=$ ne posjedujemo niti jedan navedeni predmet do $3=$ posjedujemo tri ili više navedenih predmeta) te procjenu financijske situacije obitelji (jedva spaja kraj s krajem; ima za ono što je nužno; ima dovoljno za normalan/prosječan život; prilično je dobrostojeća; bogata je). Rezultati su standardizirani z-vrijednošću te je dobiven pokazatelj ekonomskog kapitala čije su vrijednosti usporedive kod zastupljenih grupa u uzorku niže razine ekonomskog kapitala (minimalno 12) i više razine ekonomskog kapitala (maksimalno 40). Metodološko opravdanje za navedeni postupak daje i prihvatljiva unutarnja konzistencija kompozitne varijable ekonomskog kapitala studenata (Cronbach's Alpha koeficijent $=0,7$ ).

\section{Kulturni kapital}

Instrument kulturnog kapitala ispitanih studenata sastoji se od jedanaest pitanja koji se odnose na najveći postignuti stupanj obrazovanja obaju roditelja (kategorija (ne)završena osnovna škola; srednja strukovna škola u trajanju od jedne do tri ili četiri godine; gimnazija; viša škola/veleučilište; fakultet/akademija; magisterij; doktorat), procjenu posjedovanih knjiga u obiteljskom kućanstvu (nijedna knjiga; do deset knjiga; od 11 do 25 knjiga; od 26 do 100 knjiga; od 101 do 200 knjiga; od 201 do 500 knjiga; više od 500 knjiga); (ne)posjedovanje kulturnih dobara u obiteljskom kućanstvu (stručne knjige ili priručnici; klasična literatura; knjige na stranom jeziku; umjetnička djela poput slika i skulptura; nosače zvuka jazz ili klasične glazbe) te učestalosti pohađanja određenih kulturnih sadržaja (muzej ili galerija; kazalište; koncerti klasične ili jazz glazbe). Te su varijable standardizirane z-vrijednošću te je dobivena kompozitna varijabla kulturnog kapitala studenata čije su vrijednosti usporedive kod grupa niže razine kulturnog kapitala (minimalno 15) i više razine

Iz analize su isključeni ispitanici čiji su roditelji (jedan ili oba) preminuli. 
kulturnog kapitala (maksimalno 48). Metodološko opravdanje za navedeni postupak daje i zadovoljavajuća unutarnja konzistencija kompozitne varijable kulturnog kapitala studenata (Cronbach's Alpha koeficijent = 0,7).

\section{Socijalni kapital}

Instrument socijalnog kapitala obuhvaća ukupno devet pitanja o institucionalnom povjerenju i uopćenom povjerenju. Kod institucionalnog povjerenja ispitanike se tražila procjena osobnog povjerenja u osam institucija (pravosuđe, sabor, dnevni tisak, televizija, Internet, policija, sindikati, obrazovni sustav) na trostupanjskoj ljestvici (1= nikakvo ili oskudno povjerenje do $3=$ veliko ili vrlo veliko povjerenje). Uopćeno povjerenje mjeri tvrdnja o osobnom povjerenju u druge ljude putem četverostupanjske ljestvice (ne)slaganja (od 1= uopće se ne slažem do 4= potpuno se slažem). Nakon provedene standardizacije z-vrijednošću dobivena je kompozitna varijabla socijalnog kapitala studenata s vrijednostima usporedivim kod grupa s nižom razinom socijalnog kapitala (minimalno 18) i višom razinom socijalnog kapitala (maksimalno 47). Metodološko opravdanje za navedeni postupak daje i zadovoljavajuća unutarnja konzistencija kompozitne varijable socijalnog kapitala studenata (Cronbach's Alpha koeficijent $=0,7$ ).

\section{Tehnološka opremljenost}

Instrument tehnološke opremljenosti ili resursa kreiran je na temelju pitanja o broju posjedovanih novih tehnologija u obiteljskom kućanstvu (korištenjem ljestvice od $0=$ ne posjedujemo niti jedan primjerak navedene tehnologije do $3=$ posjedujemo tri ili više primjeraka navedene tehnologije) koje se odnose na stolno računalo, laptop, tablet, pametni mobitel (engl. smartphone), kameru, televiziju, digitalni fotoaparat, sustav navigacije (GPS), pametni sat, MP3 ili MP4 digitalni reproduktor, igraću konzolu. Ukupni zbroj svih navedenih tehnologija rezultirao je jedinstvenom varijablom s praktičnim rasponom od 0 do 25 te prihvatljivom unutarnjom konzistencijom (Cronbach's Alpha koeficijent $=0,7$ ).

\section{Tehnološke prakse}

Instrument tehnoloških praksi dorađen je prema istraživačkoj studiji Wilske i Pedrozo (2007) u sklopu koje su ispitivani stavovi mladih prema novim tehnologijama korištenjem peterostupanjske Likertove skale slaganja (od 1= uopće se ne slažem do $5=u$ potpunosti se slažem). S obzirom na predstavljene smjernice iz literature, u ovaj je rad uključena tvrdnja o vještom služenju novim tehnologijama i praćenju 
trendova vezanih uz nove tehnologije (od 1= uopće se ne slažem do 5= apsolutno se slažem) te učestalosti dnevnog korištenja interneta u satima (od 1= jedan sat dnevno ili manje do $6=$ pet $\mathrm{i}$ više sati dnevno te opcija $7=$ ne koristim internet dnevno). Također su uključene demografske varijable spola i dobi.

\subsection{Prikupljanje podataka i opis uzorka}

Podatci iz ovog rada proizašli su iz većeg istraživanja pod naslovom "Potrošnja i nove tehnologije među mladima u Hrvatskoj: analiza potrošačkih stilova i praksi studenata Sveučilišta u Zadru i Zagrebu", uz napomenu kako sam rad donosi originalne analize koje nisu prethodno rađene odnosno, prezentirane. Podatci su prikupljeni metodom ankete 2016. godine te su obrađeni korištenjem statističkoga programskog paketa za društvene znanosti, skraćeno (engl.) SPSS u verziji 22. Sudjelovanje $u$ istraživanju bilo je dobrovoljno te je zajamčena anonimnost svim sudionicima u fazi obrade i interpretacije rezultata, uz uvodno prezentiranje informacija o temi i svrsi istraživanja koji su navedeni na početku svakog upitnika. Također je uvodno naglašena opcija slobodnog odustajanja od sudjelovanja u istraživanju u bilo kojoj fazi ispunjavanja ankete, no većina se zatečenih studenata odazvala pozivu.

Uzorak je na prvoj razini izbora proveden prema zadanim parametrima koji se tiču nositelja studijskih programa (Sveučilište u Zadru i Sveučilište u Zagrebu), studentskog statusa i razine studija (redoviti/e studenti/ce preddiplomske razine po Bolonjskom sustavu) u određenom vremenskom periodu (ljetni semestar akademske godine 2015./2016.). Na drugoj razini su odabrani ispitanici odabirom frekventnog mjesta njihova okupljanja, po pravilu, tijekom nastave u prostorijama sveučilišta uz prethodni dogovor sa znanstvenim osobljem. Temeljni kriterij za odabirom neprobabilističkog uzorka proizlazi iz specifičnosti dvaju uključenih sveučilišta čiji je različiti ekonomski i kulturni profil studenata omogućio heterogenost osnovnog skupa uzorka stvorivši pretpostavke za istraživanje teme u predloženom teorijskom i metodološkom okviru. Glavna ograničenja realiziranog tipa uzorka jesu privid slučajnosti izbora te nemogućnost generalizacije rezultata na mlade odnosno studentsku populaciju u Hrvatskoj.

U konačnici je uključeno 1094 redovitih studentica i studenata preddiplomskih studija Sveučilišta u Zadru i Zagrebu u akademskoj godini 2015./2016. Istraživanje je bazirano na studentima zbog njihove istaknute uloge u suvremenoj literaturi o praksama i trendovima povezanima s potrošnjom i novim tehnologijama (France, 2007; Wilska i Pedrozo, 2007; Pedrozo, 2011), a osobito internetskim kupovanjem (Aziz i Wahid, 2018) u kojem su mladi i studenti među vodećim akterima u Hrvatskoj i Europskoj uniji (Eurostat, 2008-2018), a o čemu nema sustavnih uvida iz 
hrvatskog konteksta ni same sociologije. Također, u istraživanju se pošlo od teze da su studenti heterogena društvena skupina (Ilišin, 2014) čije ekonomske, kulturne i tehnološke biografije omogućavaju istraživanje teme prema postavljenim istraživačkim ciljevima.

U priloženoj su tablici navedene temeljne demografske i studijske karakteristike ispitanika.

Tablica 1. Demografske i studijske karakteristike sudionika $(\mathrm{N}=1094)$

\begin{tabular}{llcc}
\hline \multirow{2}{*}{ Spol } & Mladići & \% & N \\
\cline { 2 - 4 } & Djevojke & 33,3 & 364 \\
\hline \multirow{2}{*}{ Dob } & $18-20$ godina & 66,7 & 730 \\
\hline \multirow{3}{*}{ Godina studija } & 1. godina & 59,7 & 653 \\
\hline \multirow{2}{*}{ Sveučilište } & 2. godina & 40,3 & 441 \\
\cline { 2 - 4 } & 3. godina & 47,2 & 517 \\
\hline \multirow{2}{*}{ Znanstveno područje } & Zagreb & 30,2 & 330 \\
\cline { 2 - 4 } & Zadar & 22,6 & 247 \\
\cline { 2 - 4 } & Društveno-humanističko & 56,9 & 623 \\
\cline { 2 - 4 } & Tehničko & 43,1 & 471 \\
\cline { 2 - 4 } & Biomedicinsko & 64 & 701 \\
\cline { 2 - 4 } & Interdisciplinarno & 8,9 & 174 \\
\cline { 2 - 4 } & Biotehničko & 5,2 & 57 \\
\cline { 2 - 4 } & Prirodno & 4,6 & 50 \\
\hline
\end{tabular}

Kako je vidljivo iz priložene tablice, u istraživanju je sudjelovalo 1094 sudionika od kojih $66,7 \%$ studentica i 33,3\% studenata, što prati spolnu strukturu studentske populacije na javnim sveučilištima u Hrvatskoj u kojoj dominiraju upravo studentice: njihov se udio od akademske godine 2013./14. do 2017./2018. kretao između $62 \%$ i $63 \%$ (AZVO, 2013/14-2017/18a). Pritom se može istaknuti da na uključenim sveučilištima dominiraju upravo studentice: njih je bilo čak $77 \%$ na Sveučilištu u Zadru i 61\% na Sveučilištu u Zagrebu u akademskoj godini 2010./2011. (Farnell i dr., 2014). Najveći postotak sudionika (64\%) dolazi iz društveno-humanističkog područja koji je integriran zbog učestalih dvopredmetnih studijskih kombinacija. 
lako viša od prosjeka, struktura sudionika prema znanstvenim područjima odražava nadzastupljenost društvenih i humanističkih smjerova u Hrvatskoj koje je, gledano zajedno, od akademske godine 2013./14. do 2017./18. studiralo $50 \%$ do $52 \%$ studenata (AZVO, 2013/14 - 2017/18b). Nadalje, sudionici su bili studenti preddiplomske razine koja je u Hrvatskoj uglavnom organizirana kroz trogodišnji program, dok su u slučaju integriranih studija poput ekonomije ili medicine uključeni studenti od prve do treće studijske godine. Većina sudionika $(59,7 \%)$ broji između 18 i 20 godina te je studirala na prvoj godini $(42,7 \%)$, što odražava dobnu strukturu studentskog tijela u Hrvatskoj prilikom upisa prve godine studija (Farnell i dr., 2014).

U tablici su navedene frekvencije tehnoloških praksi sudionika istraživanja.

Tablica 2. Tehnološke prakse sudionika $(\mathrm{N}=1094)$

\begin{tabular}{|c|c|c|c|}
\hline & & $\%$ & $\mathbf{N}$ \\
\hline \multirow{7}{*}{$\begin{array}{l}\text { Dnevno koristim internet (u } \\
\text { satima) }\end{array}$} & Ne koristim dnevno & 0,5 & 6 \\
\hline & 1 i manje sati & 3,3 & 36 \\
\hline & $1-2 h$ & 9,6 & 105 \\
\hline & $2-3 h$ & 17,7 & 193 \\
\hline & $3-4 \mathrm{~h}$ & 20,5 & 224 \\
\hline & $4-5 \mathrm{~h}$ & 20,1 & 220 \\
\hline & 5 i više sati & 28,3 & 309 \\
\hline \multirow{5}{*}{$\begin{array}{l}\text { Vješto koristim nove teh- } \\
\text { nologije }\end{array}$} & Uopće se ne slažem & 1,8 & 20 \\
\hline & Uglavnom se ne slažem & 3,7 & 40 \\
\hline & Neodlučni & 13,3 & 145 \\
\hline & Uglavnom se slažem & 43,4 & 457 \\
\hline & U potpunosti se slažem & 37,8 & 414 \\
\hline \multirow{5}{*}{ Pratim tehnološke trendove } & Uopće se ne slažem & 19,1 & 208 \\
\hline & Uglavnom se ne slažem & 21,3 & 232 \\
\hline & Neodlučni & 27,1 & 297 \\
\hline & Uglavnom se slažem & 24,6 & 268 \\
\hline & U potpunosti se slažem & 7,9 & 86 \\
\hline \multirow{2}{*}{ Kupujem putem interneta } & $\mathrm{Da}$ & 62,7 & 686 \\
\hline & $\mathrm{Ne}$ & 37,3 & 408 \\
\hline
\end{tabular}


Kako je uočljivo iz priložene tablice, gotovo se svi ispitani studenti koriste internetom na dnevnoj bazi, što se moglo očekivati s obzirom na trendove u zemlji. Naime, većina stanovnika Hrvatske koristi internet svakodnevno: njih 60\% u 2015. godini ili $63 \%$ u 2016. godini, dok ih je među studentskom populacijom u obje godine registrirano 96\% (Eurostat, 2013-2016). Iz tablice se nadalje može iščitati kako petina ispitanih studenata provodi online tri do četiri ili četiri do pet sati dnevno. $U$ istraživanju Strugara i suradnika (2011) većina studenata je na internetu provodila jedan do tri sata dnevno, a značajan broj njih i više od četiri sata dnevno, dok se u ovom istraživanju pokazalo da je više od četvrtine studenata online pet i više sati dnevno. To ih referencira iznimno aktivnim korisnicima interneta na što su uputili neki autori u kontekstu bliskosti mladih generacija i korištenja novih tehnologija (France, 2007; Pedrozo, 2011). Dodatna je potvrda navedenom nalaz da se osam od deset ispitanika smatra pretežno vještim korisnicima novih tehnologija spram 5,5\% nevještih ili $13,3 \%$ neodlučnih. Po pitanju praćenja tehnoloških trendova ističu se neodlučni kojih je više od četvrtine, s time da je veći udio onih koji ne slaže s navedenom tvrdnjom: 40,4\% izjasnilo se da uglavnom ne prate tehnološke trendove, dok je približno trećina zainteresirana za tehnološke trendove. Gotovo dvije trećine kupuje putem interneta. Dobiveni postotak veći je nego u nekim ranijim istraživanjima prema kojima je registrirano 45,2\% (Anić i dr., 2013) ili 45,8\% (Strugar i dr., 2011) internetskih kupaca među studentskom populacijom u Hrvatskoj.

\section{REZULTATI}

\subsection{Kvantitativna analiza}

Cilj ovog istraživanja bio je ispitati doprinos različitih vrsta resursa na studentsku internetsku kupovinu, uzimajući u obzir njihove tehnološke prakse, dobne i spolne varijable. Stoga će se prvo utvrditi razlikuju li se studenti koji (ne)kupuju putem interneta s obzirom na posjedovani ekonomski, kulturni i socijalni kapital, tehnološku opremljenost, dnevno korištenje interneta, samoprocijenjene tehnološke vještine, praćenje tehnoloških trendova te spol i dob, i potom, jesu li isti prediktori njihovog kupovanja putem interneta.

Sukladno postavljenim istraživačkim ciljevima, proveden je niz t-testova za nezavisne uzorke kako bi se na osnovu zadanih obilježja utvrdile razlike među studentima koji kupuju putem interneta od onih koji to ne prakticiraju. Pokazalo se da internetski kupci odnosno, studenti koji kupuju putem interneta posjeduju veći ekonomski kapital, bolje su tehnološki opremljeni, više sati dnevno provode online, u većem postotku se smatraju vještim tehnološkim korisnicima i aktivnim pratiteljima tehnoloških trendova od studenata koji ne kupuju putem interneta. 
Detaljnije u potonjoj tablici.

Tablica 3. Rezultati usporedbe grupe studenata koji kupuju putem interneta (internetski kupci) u odnosu na studente koji nisu internetski kupci (Nisu IK) za ispitivana obilježja

\begin{tabular}{|c|c|c|c|c|c|}
\hline Obilježja & Vrsta kupaca & $\mathbf{N}$ & $\mathbf{M}$ & SD & $\mathbf{t}$ \\
\hline \multirow{2}{*}{ Ekonomski kapital } & internetski kupci & 523 & 27,53 & 4,92 & \multirow{2}{*}{$-3,266^{*}$} \\
\hline & Nisu IK & 304 & 26,39 & 4,61 & \\
\hline \multirow{2}{*}{ Kulturni kapital } & internetski kupci & 672 & 33,14 & 5,65 & \multirow{2}{*}{$-1,234$} \\
\hline & Nisu IK & 401 & 32,69 & 6,15 & \\
\hline \multirow{2}{*}{ Socijalni kapital } & internetski kupci & 684 & 28,91 & 5,01 & \multirow{2}{*}{0,715} \\
\hline & Nisu IK & 402 & 29,15 & 5,54 & \\
\hline \multirow{2}{*}{$\begin{array}{l}\text { Tehnološka } \\
\text { opremljenost }\end{array}$} & internetski kupci & 677 & 5,91 & 1,74 & \multirow{2}{*}{$-4,301^{*}$} \\
\hline & Nisu IK & 399 & 5,44 & 1,76 & \\
\hline \multirow{2}{*}{ Dob } & internetski kupci & 686 & 20,50 & 1,66 & \multirow{2}{*}{0,410} \\
\hline & Nisu IK & 405 & 20,54 & 1,95 & \\
\hline \multirow{2}{*}{$\begin{array}{l}\text { Dnevno korištenje } \\
\text { interneta }\end{array}$} & internetski kupci & 685 & 4,40 & 1,45 & \multirow{2}{*}{$-3,842^{*}$} \\
\hline & Nisu IK & 405 & 4,05 & 1,51 & \\
\hline \multirow{2}{*}{$\begin{array}{l}\text { Vješti/a tehnološki/a } \\
\text { korisnik/ca }\end{array}$} & internetski kupci & 686 & 4,28 & 0,82 & \multirow{2}{*}{$-8,011^{*}$} \\
\hline & Nisu IK & 405 & 3,84 & 0,95 & \\
\hline \multirow{2}{*}{$\begin{array}{l}\text { Praćenje tehnoloških } \\
\text { trendova }\end{array}$} & internetski kupci & 686 & 3,01 & 1,23 & \multirow{2}{*}{$-7,647^{*}$} \\
\hline & Nisu IK & 402 & 2,44 & 1,12 & \\
\hline
\end{tabular}

${ }^{*} p<0,05$

Hi kvadrat testom je ispitan odnos spola i kupovanja putem interneta. Ustanovljeno je da nema statistički značajne povezanosti jer gotovo podjednak udio studenata $(63,7 \%)$ i studentica $(62,4 \%)$ kupuje putem interneta $\left(X^{2}(1)=0,122, p=0,727\right)$.

Potom su se navedene varijable uključile kao prediktori u logističku regresiju kako bi se uvidjelo koja obilježja prevladavaju u objašnjenju studentskoga internet- 
skog kupovanja. Uvršteno je ukupno devet nezavisnih varijabli koje će se predstaviti u kategorijama različitih vrsta resursa (ekonomski, kulturni i socijalni kapital te tehnološka opremljenost), tehnoloških praksi (dnevno korištenje interneta, samoprocjena tehnoloških vještina, praćenje tehnoloških trendova) te demografije (spol i dob). S obzirom da je istraživana zavisna varijabla studentskoga kupovanja putem interneta (kupujete li putem interneta?) kategorijskog tipa tj. dihotomna (kodirano $0=$ ne kupuju putem interneta; $1=$ kupuju putem interneta), korištena je logistička regresija u dva koraka ili modela pri čemu su u prvom modelu uključeni posjedovani resursi kako bi im se dala prednost u objašnjenju zavisne varijable, dok su u drugom koraku ili modelu uvrštene tehnološke prakse, spol i dob.

Prvotno testirana pretpostavka o multikolinearnosti prediktora odbačena je $s$ obzirom na dobivene vrijednosti Tolerance $>0,10$ i VIF $<10$. Model se u cijelosti pokazao statistički značajnim $\left(X^{2}(9)=86,720, p<0,001\right)$ što upućuje na razlikovanje studenata koji kupuju i onih koji ne kupuju putem interneta temeljem promatranih obilježja. Hosmer-Lemeshow test podržava tvrdnju da je model dobar s obzirom da indikator predviđanja iznosi 9,68 uz značajnost 0,29 ( $p>0,05)$.

U cjelini model objašnjava između 10,2\% (Cox \& Snell R Square) i 14\% (Nagelkerke R Square) varijance internetskog kupovanja te točno klasificira $66 \%$ slučajeva što je skroman pomak od početne klasifikacije od $64 \%$.

Prema rezultatima logističke regresije u prvom koraku s uključenim resursima, statistički značajnim prediktorom studentskoga internetskog kupovanja pokazala se tehnološka opremljenost. Njezina je značajnost potvrđena u drugom koraku uz varijable praćenja tehnoloških trendova i tehnoloških vještina.

Podrobnije o vrijednostima u regresijskom modelu u Tablici 4.

Najznačajniji prediktor studentskoga kupovanja putem interneta je samoprocjena tehnoloških vještina $(B=0,43, p<0,001)$. Vjerojatnost da će odgovoriti da kupuju putem interneta je veća za one studente koji se smatraju vještim tehnološkim korisnicima od onih koji to nisu. Slično je i s praćenjem tehnoloških trendova $(B=0,28, p<0,001)$. Studenti koji su vičniji praćenju tehnoloških trendova ujedno su i skloniji prakticiranju internetskog kupovanja od svojih kolega koji su manje otvoreni za tehnološke trendove. Tehnološki resursi također su se pokazali značajnim prediktorom internetskog kupovanja $(B=0,13, p \leq 0,001)$, što znači da su studenti iz tehnološki opremljenijih kućanstava vjerojatniji internetski kupci od tehnološki niže opremljenih ispitanika. Više o dobivenim nalazima i njihovim implikacijama za temu u dijelu rasprave. 
Tablica 4. Rezultati logističke regresije za prediktore studentskoga internetskog kupovanja

\begin{tabular}{|c|c|c|c|c|}
\hline \multirow[b]{2}{*}{ Prediktor } & \multicolumn{2}{|c|}{ Model 1} & \multicolumn{2}{|c|}{ Model 2} \\
\hline & B & S.E. & B & S.E. \\
\hline Ekonomski kapital & 0,03 & 0,02 & 0,02 & 0,02 \\
\hline Kulturni kapital & $-0,01$ & 0,01 & $-0,02$ & 0,01 \\
\hline Tehnološka opremljenost & $0,15^{*}$ & 0,05 & $0,13^{*}$ & 0,05 \\
\hline Socijalni kapital & $-0,01$ & 0,02 & $-0,02$ & 0,02 \\
\hline Tehnološke vještine & - & - & $0,42^{*}$ & 0,10 \\
\hline $\begin{array}{l}\text { Praćenje tehnoloških } \\
\text { trendova }\end{array}$ & - & - & $0,28^{*}$ & 0,08 \\
\hline $\begin{array}{l}\text { Dnevno korištenje } \\
\text { interneta }\end{array}$ & - & - & 0,05 & 0,06 \\
\hline Spol & - & - & $-0,15$ & 0,18 \\
\hline Dob & - & - & 0,06 & 0,05 \\
\hline Cox \& Snell $R^{2}$ & \multicolumn{2}{|c|}{$3 \%$} & \multicolumn{2}{|c|}{$10,2 \%$} \\
\hline Nagelkerke $\mathrm{R}^{2}$ & \multicolumn{2}{|c|}{$4 \%$} & \multicolumn{2}{|c|}{$14 \%$} \\
\hline
\end{tabular}

${ }^{*} p<0,05$

\subsection{Kvalitativna analiza}

Nakon izloženih statističkih analiza, a u svrhu kvalitativnog produbljivanja odrednica studentskoga internetskog kupovanja, slijedi osvrt na studentske upise o razlozima njihova neprakticiranja internetskog kupovanja temeljem mogućnosti otvorenih odgovora. Većina odgovora se grupirala u dvije glavne teme nazvane nepovjerenje te fizička kupovina.

U prvom su slučaju ispitanici vlastito neprakticiranje internetskog kupovanja objašnjavali strahom od zloupotreba osobnih podataka te mogućih financijskih prevara. Neki od odgovora na tu temu su:

- Bojim se povrede privatnosti i bankovnog računa.

- Bojim se krađe podataka.

- Strah od upada na račun, prijevare prilikom kupnje od strane prodavača.

- Nemam interes, prekomplicirani i predosadni formulari za izradu profila i strah od piratstva podataka.

- Rizik od cyberpljačke i krađe identiteta. 
- Zato što smatram da moji podatci nisu sigurni.

- Zato što nemam povjerenja da će moji podaci ostati tajni.

- Nisam o tome puno informirana, ne želim ostavljati broj kartice na internetu jer postoji mogućnost krađe.

- Jer me strah da ne ostanem bez novaca.

- Nesigurnost i nezaštićenost kartičnih i osobnih podataka.

Uz aspekt osobnih podataka i financijskih rizika, tema nepovjerenja obuhvaća i ispitanikove kritike atribucija online proizvoda uz fokus na opću kvalitetu, primjerice:

- Nije pouzdano, niti sigurno, nemam doživljaj kako stvari izgledaju kada su virtualne.

- Proizvodi se često razlikuju uživo u odnosu na virtualno, slabije su kvalitete, volim isprobati i opipati ono što kupujem.

- Zbog nepovjerenja u kvalitetu artikla i dostave.

- Nemam povjerenja u kvalitetu ponuđenog proizvoda ja ga ne mogu pogledati prije kupnje.

- Nisam sigurna u kupovinu preko interneta, u kvalitetu i ispravnost onoga što kupujem.

- Nemam povjerenja i previše se čeka na isporuku.

- Nemam povjerenja u kvalitetu proizvoda koja je na slici s onom u stvarnosti.

- Ne vjerujem u kvalitetu i valjanost robe koja se kupuje preko interneta.

- Riskantno, nekvalitetno, nikad ne znaš što će ti doći.

- Nepovjerenje u kvalitetu proizvoda i usluge.

Druga tema nazvana fizičko kupovanje okuplja ispitanikove usporedbe internetskog kupovanja s fizičkom opcijom, pri čemu ističu raznovrsne prednosti potonje, odnosno identificiraju klasične probleme kupovanja na neviđeno:

- Ne kupujem zato što uživo ne mogu vidjeti traženi predmet i procijeniti ga.

- Više volim isprobati proizvod uživo nego kupovati i možda promašiti s odabirom.

- Nemam potrebe za kupnjom preko interneta, sve mi je dostupno putem supermarketa.

- Volim vidjeti i opipati proizvod prije nego što ga kupim.

- Jednostavno je bolje vidjeti nešto prije nego što kupim. Kupnja preko interneta nije zanimljiva kao obična kupovina.

- Ako mogu u dućanu, nema korist kupovati online. A i znam šta kupujem uživo.

- Nemam naviku, volim vidjeti proizvod, svega ima u trgovinama.

- Više volim stvari vidjeti uživo i dobiti dojam o njima, a i sigurnije se osjećam. 
- Nema potrebe. Sve uspijem odraditi/kupiti inače, a uglavnom kupujem hranu ili odjeću što volim pogledati i provjeriti, isprobati prije kupnje.

- Želim znati što kupujem, zato ako me nešto zanima, to potražim u trgovinama, centrima i nađem!

Među ostalim je razlozima suzdržavanja od internetskog kupovanja neznanje i neinformiranost (npr., Nemam naviku kupovanja preko interneta niti sam dovoljno upoznat s mogućnostima Internet kupovine; Nisam informirana o tome baš) te lijenost i nezainteresiranost (npr., Ne da mi se; Ne postoji konkretan razlog, nisam došla u priliku kupovati nešto preko interneta; Nije mi zanimljivo). Prisutna su i objašnjenja tehničke prirode, uglavnom u vezi računa i kartičnog plaćanja (npr., Ne posjedujem kartice, koje su neophodne za kupovinu na internetu; Nemam PayPal; Nemam svoj račun ili što je već potrebno). Zanimljivo je istaknuti odgovore pojedinih ispitanika koji su odgovorili da osobno ne kupuju osobno putem interneta, nego to netko radi za njih (npr. Ja osobno nisam jer su za to potrebni računi koje ja nemam, ali tata kupuje; Kupnju uvijek obavljaju moju roditelji; Jer imam stariju sestru koja to radi za mene; Ako trebam kupiti nešto preko interneta, taj pothvat proslijedim svome ocu; Naručujem preko drugih).

\section{RASPRAVA}

$\mathrm{Na}$ osnovu obavljenih analiza može se sumirati kako kulturni i socijalni kapital, dob i spol ne predstavljaju utjecajne odrednice studentskoga internetskog kupovanja u Hrvatskoj. U dijelu dobivenog nalaza studentsko se internetsko kupovanje referencira biografski znatno rasterećenom praksom, što korespondira sa stavom nekih autora poput Bigne i suradnika (2005), kako s razvojem novih tehnologija, napose interneta, dolazi do sve veće homogenosti njegovih korisnika. Ova bi se opaska osobito mogla primijeniti na mlade koje visoka tehnološka izloženost od najranije dobi predisponira, na određeni način i socijalizira, za korištenje novih tehnologija (France, 2007; Pedrozo, 2013). Shodno tomu, ispitanici u ovom radu, mahom mladi do 30 godina, predstavljaju iznimno aktivne internetske korisnike od kojih je većina $(68,9 \%)$ online tri ili više sati dnevno, uglavnom se smatraju vještim tehnološkim korisnicima $(81,2 \%)$, gotovo trećina $(32,5 \%)$ ih prati tehnološke trendove, dok su u većini $(62,7 \%)$ skloni kupovanju putem interneta. Istodobno se s razvojem novih tehnologija mijenjaju društvene navike vezane uz njihovo korištenje ili socijalni profili korisnika, poput atribucija o internetu kao primarno tehnološkoj domeni muškaraca (Dittmar i dr., 2004) ili početni socijalni bias njegovih korisnika (Hernandez i dr., 2011). Hernandez i suradnici (2011) navode kako je s tehnološkim razvojem i unapređenjem online korisničkog iskustva prevladano početno socioekonomsko 
uvjetovanje internetskih praksi te su se općenito smanjile početne zapreke u njegovom pristupu i korištenju kod većine populacije zapadnih zemalja. No, razlikovni ekonomski, kulturni i tehnološki čimbenici odjeljuju kontekst razvijenih zemalja od zemalja u razvoju oblikujući odnos s novim tehnologijama i kod generacija mladih. Prema Pedrozo (2013), njihov utjecaj može u bitnome ograničiti šanse mladih za sudjelovanjem na zahtjevnim i globaliziranim tržištima rada. Shodno tomu, Krištofić (2007) u kontekstu hrvatskog društva upozorava da, iako su mladi dominantni korisnici interneta, prihodi i obrazovanje umnogome određuju njihove tehnološke prakse, a ne mladost po sebi. U tom se smjeru može primijetiti bliskost između potvrđene razlikovnosti studenata koji kupuju putem interneta od onih koji tomu nisu vični s obzirom na posjedovani ekonomski kapital i dimenziju tehnološke opremljenosti čijim se analitičkim izdvajanjem bistri širina socioekonomskih ukorijenjenosti suvremenih praksa poput internetskog kupovanja. To je ujedno pomiče s opće retorike izbora na konkretne studentske pozicije u ekonomskom, odnosno tehnološkom polju. Naime, internetske kupce karakterizira bolja opremljenost ekonomskim kapitalom i novim tehnologijama uz aktivnije korištenje interneta, naprednije tehnološke vještine i veći interes za praćenjem tehnoloških trendova od ispitanih studenata koji ne kupuju putem interneta. Dobiveni se nalaz stoga može sagledati kroz opasku llišin (2014) kako životne šanse i životni izbori mladih nisu uopćeno bazirani na individualnim principima, nego se oblikuju društvenom strukturom i dostupnim resursima. Doprinos je ovog istraživanje u identificiranju takvih kulturnih filtera u domeni potrošnje i novih tehnologija, što daje uvid u slojevitost rizika s kojima se susreću mladi odnosno, studenti u Hrvatskoj.

Dodatne spoznaje na tu temu pruža analiza prediktora kupovanja putem interneta prema kojoj posjedovani tehnološki resursi, tehnološke vještine i praćenje tehnoloških trendova najbolje predviđaju studentsko internetsko kupovanje. Time se doznalo da je odnos nove tehnologije i studenata u Hrvatskoj proširen s aspekta pristupa ili opremljenosti novim tehnologijama na aspekt tehnoloških vještina i interesa, što signalizira složeni kontekst tehnoloških nejednakosti. O tome su pisali $i$ neki domaći sociolozi zaključivši: "Računalne vještine čine jezgru prenosivih vještina (transferable skills), čija je važnost osobito naglašena u studentsko doba" (Potočnik, 2014: 378). Autori kao što su van Dijk i Hacker (2003) upozorili su pak da tehnološka nejednakost nije rješiva pukim posjedovanjem računala i internetskog priključka te su identificirali više pripadajućih razina: psihološki ili mentalni pristup prati nezainteresiranost za nove tehnologije, pa i strah od računala; materijalni se pristup bazira na posjedovanju tehnologija poput računala i internetskog priključka; nedostatak vještina znači izostajanje potpore razvoju tehnoloških vještina; manjak uporabe upućuje na manjak mogućnosti tehnološkog korištenja. Popularizacijom i omasovljavanjem tehnologija, autori pretpostavljaju prijelaz s mentalnog 
i materijalnog pristupa na aspekt vještina i korištenja, što nije slučaj s ispitanim studentima kod kojih je prikladnije govoriti o prožimanju različitih razina tehnoloških nejednakosti. To znači da nije došlo do smjene razina pristupa, nego njihovog koegzistiranja u hibridnom modelu koji nije bez rizika. Primjerice, van Deursen i van Dijk (2014) adresiraju rizik od višerazinskog društvenog isključenja upravo na tehnološkoj osnovi ističući kako su nejednakosti i podjele tradicionalne sastavnice društva od kojih neke upravo internet (re)producira i ubrzava. Istraživanje Wilske i Pedrozo (2007) shodno tome pokazuje kako se na radikalne kulturne i društvene efekte novih tehnologija nadograđuju druge vrste isključenosti u različitim sferama potrošačkog društva, što nas vraća na uvodno izloženu Giddensovu (1991) konstataciju o dvostrukoj modernosti koja s jedne strane propagira osobnu autonomiju i heterogeni izbor, a s druge strane različitim rizicima opterećuje biografije pojedinaca. Iz navedenog se formira zaključak da suvremena potrošačka i tehnološka kultura intenzivira društvenu podjelu na one koji mogu i ne mogu trošiti, kao i na one koji imaju pristup i potrebne vještine za korištenje novih tehnologija. Ti se procesi očito prelijevaju na virtualnu sferu, pri čemu dobiveni prediktori studentskoga internetskog kupovanja mogu ukazivati na segregaciju ulaznih mehanizama, dok se temeljem ustanovljenih razlika među studentima koji (ne) kupuju putem interneta razotkriva unutarnja konsolidacija prakse.

lako u ulozi prediktora studentskoga internetskog kupovanja nije pronađena značajnost socijalnog kapitala operacionaliziranog aspektom institucionaliziranog i uopćenog povjerenja, u priloženoj narativnoj istraživačkoj građi upravo se istaknula spona povjerenja i internetskog kupovanja. U ovom su dijelu, s ciljem pružanja dubinskog uvida u temu rada i svojevrsnog usmjerenja za buduća istraživanja sličnog interesa, analizirani otvoreni odgovori studenata koji ne kupuju putem interneta. Većina je studentskih obrazloženja vlastitog neprakticiranja internetskog kupovanja referencirana tematikom nepovjerenja, bilo da je riječ o nepovjerenju u status osobnih podatka te s time povezanim financijskim rizicima ili nepovjerenju u ispravnost online proizvoda. U usporedbi s nalazima Anića i suradnika (2013) o studentima koji su na prvom mjestu ograničavajućih čimbenika online trgovina naveli nemogućnost razgledavanja proizvoda odnosno, kompliciranu politiku povrata proizvoda, studente u ovom istraživanju očito više brinu opća sigurnosna pitanja. No, kako je zorno iz sekcije odgovora nazvane fizička kupovina, riječ je o perceptivnim kupcima s praktičnom logikom u kontekstu koje važu komparativne prednosti virtualne naspram fizičke opcije dajući prednost beneficijama potonje, posebno mogućnosti vizualnog kontakta, direktne procjene kvalitete i isprobavanja robe. Njihove kritike na račun internetskog kupovanja na općoj razini potvrđuju da je internet kao komercijalni medij u usponu u svojevrsnom sučeljavanju s već utemeljenim sustavom fizičke kupovine, pri čemu još uvijek nije dosegnuo njegov status 
(Soopramanien i Robertson, 2007). Na iskustvenoj razini dijela studenata utvrđena preferencija tradicionalnog modusa kupovanja može ukazivati da nisu uopće ni prijemljivi za suvremene, tehnološki posredovane, potrošačke trendove. Pritom valja podsjetiti da se dobiveni rezultati ne mogu uopćavati na cijelu populaciju studenata u Hrvatskoj, s obzirom na to da nisu proizišli iz reprezentativnog uzorka. No, oni mogu ponuditi svojevrstan orijentir u razumijevanju odrednica studentskoga internetskog kupovanja u Hrvatskoj, o čemu nema sustavnih istraživanja, a ujedno i potaknuti nove znanstvene spoznaje.

\section{ZAKLJUČAK}

Ovaj rad je donio empirijske uvide o studentskom internetskom kupovanju u Hrvatskoj. S obzirom na to da je riječ o globalno popularnom fenomenu o kojem nema mnogo osvrta iz područja društvenih znanosti u Hrvatskoj, napose sociologije, nastojala se osuvremeniti domaća literatura na tu temu i pružiti istraživačka baza za interdisciplinarne nadogradnje.

Ono što ovaj rad izdvaja odnosno, predstavlja njegov doprinos, primjena je bourdieuovskog pristupa kojim internetsko kupovanje nije promišljena samo kao suvremena društvena činjenica $u$ afilijaciji individualnog izbora, nego i kao dinamični neksus naslijeđenih dispozicija i resursa što potencijalno širi polje rasprave s maloprodajnih strategija i tržišnih alata na socioekonomske, kulturne, socijalne i tehnološke uvjetovanosti odnosa mladih i novih tehnologija. Sukladno tomu, studentske se potrošačke i tehnološke prakse sagledavaju u sociokulturnoj uvjetovanosti, ne samo virtualnoj mobilnosti. Takav pristup daje na aktualnosti klasičnoj i suvremenoj sociološkoj građi, dok istodobno u samoj struci aktualizira tekuće trendove poput internetskog kupovanja.

Korištenjem heterogenoga metodološkog pojmovnika radom se nastojalo utvrditi postoje li razlike među studentima koji (ne) kupuju putem interneta, odnosno predisponiraju li različiti resursi njihovo internetsko kupovanje ili su odlučujuće varijable spola, dobi i tehnoloških praksi. Na prvoj se analitičkoj razini utvrdilo da posjedovani ekonomski kapital i tehnološka opremljenost uz set varijabli vezanih uz tehnološke prakse razlikuje studente koji kupuju odnosno, ne kupuju putem interneta na način da je veća razina posjedovanja tih resursa i aktivnija participacija u tehnološkim praksama obilježje internetskih kupaca. Na drugoj se analitičkoj razini ispostavilo da su tehnološka opremljenost uz tehnološke vještine i izraženi interes za tehnološkim trendovima značajni prediktori studentskog kupovanja putem interneta. Iz dobivenih se rezultata očitovala višerazinska tehnološka predisponiranost studentskoga internetskog kupovanja, dakle i u vidu njihove tehnološke opremljenosti te posjedovanih tehnoloških vještina i interesa. Dok su neki autori 
pretpostavili smjenu tehnoloških nejednakosti s aspekta posjedovanja na aspekt vještina, na slučaju ispitanih studenata ustanovilo se njihovo koegzistiranje u svojevrsnom hibridnom modelu koji je naznačio rizik od višerazinske digitalne podjele, koja umnogome može kočiti njihovo uključivanje i participiranje u globalnim tokovima današnjice. Nadalje je raslojavanje studenata koji (ne) kupuju putem interneta na bazi ekonomskog kapitala razotkrilo da "stari" mediji nejednakosti generiraju (i) suvremene potrošačke prakse, moguće kroz sve suptilnije gradiranje vlastitih mehanizama stratifikacije. U vidu toga se dobivena značajnost dimenzije tehnološke opremljenosti može protumačiti kao tehnološka formacija ili ekstenzija ekonomskih biografija studenata, što pokazuje potrebu za dovitljivim analitičkim rješenjima u istraživanju internetskog kupovanja. Potvrđuje to i nalaz kako ekonomski resursi nisu značajni prediktori studentskoga internetskog kupovanja, ali i kako postoji značajna razlika u posjedovanju ekonomskog kapitala studenata koji ne kupuju od onih koji kupuju putem interneta, pri čemu veći ekonomski kapital krasi potonje te adresira bliskost potrošačke aktivnosti i ekonomske opremljenosti u virtualnoj domeni. lako nije potvrđena značajnost socijalnog kapitala operacionaliziranog aspektom povjerenja, priloženi je kvalitativni materijal promovirao upravo aspekt (ne) povjerenja u značajni čimbenik koji priječi, odnosno u bitnome definira spremnost studenata za kupovanje putem interneta, istodobno prokazujući razvojne izazove same prakse.

Zaključno se studentsko internetsko kupovanje u kontekstu hrvatskog društva i perspektivi sociologije zaokružuje u kombinatorici osobnog izbora i strukturalnih (ne)mogućnosti, što otvara njezina daljnja tumačenja i razrade u struci i interdisciplinarnim suradnjama. Ujedno se dobivenim nalazima podcrtava fenomenološka ozbiljnost potrošačkih i tehnoloških praksi kao aktualnih označitelja suvremene kulture mladih koja je u virtualnoj zbilji referentna odnosima nejednakosti te nepovjerenja. 


\section{LITERATURA}

AZVO - Agencija za znanost i visoko obrazovanje (2013/14-2017/18a). Udio studentica po akademskoj godini i vrsti ustanove (2013/14 - 2017/18a). https://www.azvo. $\mathrm{hr} / \mathrm{hr} / \mathrm{visoko-obrazovanje/2115-udio-studentica-po-akademskoj-godini-i-vrsti-}$ ustanove-2013-14-2017-18 (1. studenoga 2019.)

AZVO - Agencija za znanost i visoko obrazovanje (2013/14-2017/18b). Udio studenata u pojedinom području znanosti (2013/14 - 2017/18b). https://www.azvo.hr/hr/visokoobrazovanje/statistike/2123 (1. studenoga 2019.)

Akhter SH (2003). Digital Divide and Purchase Intention: Why Demographic Psychology Matters, Journal of Economic Psychology, 24 (3): 321-327. https://doi.org/10.1016/ S0167-4870(02)00171-X

Akhter SH (2012). Who Spends More Online? The Influence of Time, Usage Variety, and Privacy Concern On online Spending, Journal of Retailing and Consumer Services, 19 (1): 109-115. https://doi.org/10.1016/j.jretconser.2011.10.002

Anić ID, Marković M i Vouk R (2013). Stavovi mladih potrošača o etičnosti prodaje online maloprodavača, Poslovna izvrsnost, 7 (2): 9-21.

Aziz NNA i Wahid NA (2018). Why Consumers are Hesitant to Shop Online: The Major Concerns towards Online Shopping, International Journal of Academic Research in Business and Social Sciences, 8 (9): 1175-1185. https://doi.org/10.6007/IJARBSS/v8i9/4689

Bigne E, Ruiz C i Sanz S (2005). The Impact of Internet User Shopping Patterns and Demographics on Consumer Mobile Buying Behaviour, Journal of Electronic Commerce Research, 6 (3): 193-209.

Bourdieu P (1997). The Forms of Capital. U: Henry Halsey A, Lauder H, Brown P i Stuart Wells A (ur.). Education: Culture, Economy, and Society. Oxford: Oxford University Press, 46-58.

Bralić A, Jadrić M i Ćukušić M (2014). Factors Associated With Static-Price Online Group Buying, Ekonomska misao i praksa, 1: 65-84.

Campbell C (1987). The Romantic Ethic and the Spirit of Modern Consumerism. Oxford: Basil Blackwell.

Choudhury D i Dey A (2014). Online Shopping Attitude among the Youth: A Study on University Students, International Journal of Entrepreneurship and Development Studies, 2 (1): 23-32.

Ciunova-Shuleska A, Grishin M i Palamidovska N (2011). Assessing Young Adults' Attitudes Toward Online Shopping in the Republic of Macedonia, Ekonomski pregled, 62 (12): 752-772.

Dittmar H, Long K i Meek R (2004). Buying on the Internet: Gender Differences In Online and Conventional Buying Motivations, Sex Roles, 50 (5): 423-444. https://doi. org/10.1023/B:SERS.0000018896.35251.c7

DZS - Državni zavod za statistiku Republike Hrvatske (2018). Primjena informacijskih i komunikacijskih tehnologija (IKT) u kućanstvima i kod pojedinaca u 2018., prvi rezultati. https://www.dzs.hr/Hrv_Eng/publication/2018/02-03-02_01_2018.htm (1. studenoga 2019.) 
Eurostat (2008-2018). Internet users who bought or ordered goods or services for private use in the previous 12 months by age group, EU-28, 2008-2018. https:// ec.europa.eu/eurostat/statistics-explained/index.php?title=E-commerce_statistics_for_ individuals\#General_overview (1. srpnja 2019.)

Eurostat (2012-2018; 2013-2018; 2014-2018). Internet purchases by individuals. http:// appsso.eurostat.ec.europa.eu/nui/show.do?dataset=isoc_ec_ibuy\&lang=en (1. srpnja 2019.)

Eurostat (2013-2016). Individuals - frequency of internet use. https://appsso.eurostat. ec.europa.eu/nui/submitViewTableAction.do (1. studenoga 2019.)

Eurostat (2018). Digital economy and society statistics - households and individuals. https:// ec.europa.eu/eurostat/statistics-explained/index.php?title=Digital_economy_and_ society_statistics_-_households_and_individuals_(1. studenoga 2019.)

Farag S, Dijst M i Lanzendorf M (2003). Exploring the Use of E-shopping and Its Impact on Personal Travel Behaviour in the Netherlands, Transportation Research Record, 1858 (1): 47-54. https://doi.org/10.3141/1858-07

Farag S, Schwanen T, Dijst M i Faber J (2007). Shopping Online and/or In-store? A Structural Equation Model of the Relationships Between E-shopping and In-store Shopping, Transportation Research Part A: Policy and Practice, 41 (2): 125-141. https:// doi.org/10.1016/j.tra.2006.02.003

Farag S, Weltevreden J, van Rietbergen T, Dijst M i van Oort F (2006). E-Shopping in the Netherlands: Does Geography Matter?, Environment and Planning B: Urban Analytics and City Science, 33 (1): 59-74. https://doi.org/10.1068/b31083

Farnell T, Matković T, Doolan K i Cvitan M (2014). Socijalna uključivost visokog obrazovanja u Hrvatskoj. Zagreb: Institut za razvoj obrazovanja.

France A (2007). Understanding Youth in Late Modernity. Maidenhead: Open University Press.

Giddens A (1991). Modernity and Self-Identity. Self and Society in the Late Modern Age. Stanford: Stanford University Press.

Grabner-Kraeuter S (2002). The Role of Consumers' Trust in Online-Shopping, Journal of Business Ethics, 39 (1-2): 43-50. https://doi.org/10.1023/A:1016323815802

Hernandez B, Jimenez JM i Martín J (2011). Age, Gender and Income: Do They Really Moderate Online Shopping Behaviour?, Online Information Review, 35 (1): 113-133. https://doi.org/10.1108/14684521111113614

Ilišin V (2014). Uvod u istraživanje hrvatskih studenata. U: Ilišin V (ur.). Sociološki portret hrvatskih studenata. Zagreb: Institut za društvena istraživanja u Zagrebu, 11-28.

Jordan G, Marič M i Leskovar R (2018). Impact of Fear of Identity Theft and Perceived Risk on Online Purchase Intention, Organizacija, 51 (2): 146-155. https://doi.org/10.2478/ orga-2018-0007

Kiyici M (2012). Internet Shopping Behavior of College of Education Students, The Turkish Online Journal of Educational Technology, 11 (3): 202-214.

Knežević B, Delić M i Ptić K (2016). Clothing Buying Motives and Store Selection Criteria The Case of Croatian Adolescents, Ekonomski vjesnik, 29 (S): 105-116.

Krištofić B (2007). Digitalna nejednakost, Sociologija i prostor, 45 (2): 165-181.

Kumar S i Maan S (2014). Status and Scope of Online Shopping: An Interactive Analysis through Literature Review, International Journal of Advance Research in Computer Science and Management Studise, 2 (12): 100-108. 
Lammers BH, Curren MT, Cours D i Lammers ML (2003). Social Image of Students Who Shop and Don't Shop Online, Psychological Reports, 92 (3): 823-827. https://doi. org/10.2466/pr0.2003.92.3.823

Lester DH, Forman AM i Loyd D (2005). Internet Shopping and Buying Behavior of College Students, Services Marketing Quarterly, 27 (2): 123-138. https://doi.org/10.1300/ J396v27n02_08

MasterCard Worldwide Insights (2008). Online Shopping in Asia/Pacific-Patterns, Trends and Future Growth. https://docuri.com/download/asia-pacific-onlineshop_59c1d318f581710b28652ba7_pdf (1. srpnja 2019.)

Perea y Monsuwé T, Dellaert B i de Ruyter K (2004). What Drives Consumers to Shop Online? A literature Review, International Journal of Service Industry Management, 15 (1): 102-121. https://doi.org/10.1108/09564230410523358

Nikodem K i Črpić G (2014). O (ne)održivosti veza između povjerenja i demokracije. U: Baloban J, Nikodem K i Zrinščak S (ur.). Vrednote u Hrvatskoj i u Europi. Komparativna analiza. Zagreb: Kršćanska sadašnjost i Katoličko bogoslovni fakultet Sveučilišta u Zagrebu, 259-307.

Norum PS (2008). Student Internet Purchases, Family and Consumer Sciences Research Journal, 36 (4): 373-388. https://doi.org/10.1177/1077727X08318705

Park J i Kim J (2007). The Importance of Perceived Consumption Delay in Internet Shopping: Time-Related Information, Time Risk, Attitude, and Purchase Intention, Clothing and Textiles Research Journal, 25 (1): 24-41. https://doi.org/10.1177/0887302X06296869

Pavić-Rogošić L (2007). Što je socijalni kapital?

http://www.odraz.hr/media/404867/\%C5\%A1to\%20je\%20socijalni\%20kapital.pdf (1. studenoga 2019.)

Pedrozo S (2011). To be 'Cool' or Not to be 'Cool': Young People's Insights on Consumption and Social ilssues in Rio de Janeiro, Journal of Youth Studies, 14 (1): 109-123. https:// doi.org/10.1080/13676261.2010.506525

Pedrozo S (2013). New Media Use in Brazil: Digital Divide or Digital Inclusion?, Online Journal of Communication and Media Technologies, 3 (1), 144-163.

Peračković K (2013). Osnovni pojmovi u sociologiji potrošnje. U: Čolić S (ur.). Potrošačka kultura i konzumerizam. Zagreb: Institut društvenih znanosti Ivo Pilar, 25-47.

Potočnik D (2014). Socijalni status studenata. U: llišin V (ur.). Sociološki portret hrvatskih studenata. Zagreb: Institut za društvena istraživanja u Zagrebu, 57-96.

Raamat R, Keller M, Martensen A i Tufte B (2008). Young Estonians and Danes as Online Shoppers. A Comparative Study, Young, 16(3): 303-324. https://doi. org/10.1177\%2F110330880801600304

Soopramanien DGR i Robertson A (2007). Adoption and Usage of Online Shopping: An Empirical Analysis of the Characteristics Of 'Buyers', 'Browsers' and 'Non-Internet Shoppers', Journal of Retailing and Consumer Services, 14 (1): 73-82. https://doi. org/10.1016/j.jretconser.2006.04.002

Spajić Vrkaš V i Potočnik D (2017). Mladi i obrazovanje pred izazovima globalne konkurentnosti. U: Ilišin V i Spajić Vrkaš V (ur.). Generacija osujećenih. Mladi u Hrvatskoj na početku 21. stoljeća. Zagreb: Institut za društvena istraživanja u Zagrebu, 75-141.

Strugar I, Knežević B i Jaković B (2011). Potencijali i problemi e-trgovine u studentskoj populaciji, Zbornik Ekonomskog fakulteta u Zagrebu, 9 (2): 155-173. 
Swinyard WR i Smith SM (2003). Why People (Don't) Shop Online: A Lifestyle Study of the Internet Consumer, Psychology \& Marketing, 20 (7): 567-597. https://doi.org/10.1002/ mar.10087

Štulec I, Petljak K i Naletina D (2018). S-commerce: How to Turn \# into \$, InterEULawEast, 5 (1): 1-14. https://doi.org/10.22598/iele.2018.5.1.1

Tang T-W i Chi W-H (2005). The Role of Trust in Customer Online Shopping Behavior: Perspective of Technology Acceptance Model. https://web.archive.org/ web/20060512124109/http://www.casos.cs.cmu.edu/events/conferences/2005/2005_ proceedings/Tang.pdf (1. studenoga 2019.)

The Statistics Portal (2019). Retail E-commerce Sales in the United States from 2017 to 2023 (in million U.S. dollars). https://www.statista.com/statistics/272391/us-retail-ecommerce-sales-forecast/ (1. srpnja 2019.)

van Deursen AJAM i van Dijk JAGM (2014). The Digital Divide Shifts to Differences in Usage, New Media \& Society, 16(3): 507-526. https://doi.org/10.1177\%2F1461444813487959

van Dijk JAGM i Hacker K (2003). The Digital Divide as a Complex and Dynamic Phenomenon, Information Society, 19 (4), 315-326. https://doi.org/10.1080/01972240309487

Vojvodić K i Matić M (2015). Generation Y Online Buying Patterns, Tržište, 27 (2): 171-188.

Wilska T-A i Pedrozo S (2007). New Technology and Young People's Consumer Identities: A Comparative Study Between Finland and Brazil, Young, 15 (4): 343-368. https://doi. org/10.1177/110330880701500402 


\title{
Sociological Overview of the Determinants of Internet Purchase among Students in Croatia
}

\author{
Ivana BRSTILO LOVRIĆ \\ Catholic University of Croatia \\ ivana.brstilo@unicath.hr
}

\section{ABSTRACT}

Valorising Internet purchase as a current phenomenon that has recently been rapidly growing worldwide, this paper points to the lack of social, especially sociological, analysis of the topic in the context of Croatian society. By reviewing the literature about Internet buyers' profiles, a research framework has been developed for conducting a survey among students, who are recognised as the anticipators of contemporary consumer and technological trends. Using operationalised multiple forms of capital with demographic variables and variables of technological resources and practices, the analysis of the determinants of Internet purchase among students in Croatia $(N=1094)$ has been conducted. Original empirical survey findings showed that students' Internet purchase is predicted most reliably by their technological resources, technological skills and interest in such a way that students better equipped with new technologies, with pronounced technological skills and an interest in following technological trends are more likely to be Internet consumers. The aspects of technological resources and practices combined with economic capital have been affirmed as significant factors in distinguishing students who are (not) buying via the Internet, which underlined multilevel inequalities within the perspective of students' Internet purchase. A prominent concern about online risks and traditional attachment to physical consumption turned out to be the respondents' main reasons not to buy via the Internet, which encompassed its developmental dynamics within the topics of social inequality and distrust.

Key words: Internet purchase, Internet buyers, students, Croatia, capital, technological resources and practices, online risks 
